\title{
Upaya Melestarikan Permainan Tradisional Engklek melalui Teknologi Digital Interaktif.
}

\author{
Ati Bahiyati Utami Putri ${ }^{1}$, Noor Hasyim² \\ 1,2Program Studi Desain Komunikasi Visual, Fakultas ILmu Komputer \\ Universitas Dian Nuswantoro
}

\begin{abstract}
Traditional games which involved fine motor skill are becoming obsolete nowadays, one of them is engklek. In addition to technological developments, the increasingly diminishing playgrounds and the growing individuality of the urban community has made traditional games much more forgotten. The preservation of engklek needs to be done through a contemporary approach involving recent technologies, one of them is using video games. Video games has potential to grow children's curiosity towards some knowledge that become increasingly rare. The aim of digitization of englek is to introduce traditional games in order to preserve the culture of traditional game for Indonesian children, especially for those whom live in urban areas today. The final result of this design process is an Android game application called PERON Engklek that would introduce traditional games through digital technology for children nowadays. By doing so, it would motivate them to play with their friends.
\end{abstract}

Kata Kunci: engklek, video game, design, traditional game

\section{PENDAHULUAN}

Engklek merupakan permainan tradisional yang memiliki bermacam-macam sebutan di berbagai daerah, seperti Gala Asin, Tepok Gunung, Ingkling, Teklek, Sundamanda, dan lain-lain namun pada umumnya peraturan permainannya sama. Permainan ini adalah permainan populer pada masa kolonial Belanda bernama zondaag mandaag yang kemudian dimainkan oleh anak-anak pribumi sehingga semakin meluas ke tanah air. Permainan engklek termasuk permainan bergerak yaitu berhubungan dengan aktifitas motorik dimana mengharuskan anakanak yang memainkannya utuk melompati petak-petak yang tergambar di tanah atau lantai secara bergiliran. permainan tradisional engklek merupakan permainan yang memiliki prosedur dan bentuk yang bervariasi terbanyak, kompleks. Permainan engklek selain menyenangkan juga mempunyai banyak manfaat dalam 4 aspek 
kecerdasan antara lain kecerdasan kinestetik, kecerdasan interpersonal, kecerdasan intrapersonal dan kecerdasan naturalis (Sujianto, 1996). Walaupun mempunyai banyak manfaat, seiring meluasnya globalisasi yang berdampak pada perkembangan teknologi, pada saat ini permainan tradisional yang melatih gerak motorik mulai ditinggalkan. Selain perkembangan teknologi, lahan tempat bermain yang semakin berkurang dan sifat individualitas yang semakin berkembang pada masayarakat kota semakin membuat permainan tradisional dilupakan. Herry Supriyono selaku seksi atraksi budaya Dinas Kebudayaan dan Pariwisata Kota Semarang mengatakan modernisasi yang bergerak lambat namun telah membuat permainan modern berkembang pesat dengan berbagai macam jenis yang semakin variatif, permainan tradisional kini kian tersisih, tertinggal, bahkan terlupakan. Mulai dari anak-anak sampai dewasa kini asyik di depan layar komputer, laptop, playstation dan handphone untuk bermain game digital karena permainan tersebut tidak memerlukan tempat khusus dan luas serta bisa dimainkan sendiri. Hal ini bertambah luas semakin sejalan dengan dibuka tempat-tempat permainan di berbagai pusat perbelanjaan. Padahal permainan tradisional pada dasarnya lebih membentuk anak dalam berbagai aspek salah satunya adalah kemampuan motorik pada permainan tradisional engklek.
Setiono dari seksi nilai budaya membenarkan bahwa permainan tradisional di masyarakat saat ini mengalami penurunan drastis, dan untuk menyikapinya Dinas Kebudayaan dan Pariwisata Provinsi Jawa Tengah memberikan kebijakan yaitu mengadakan program setiap tahun sekali dimana membantu daerah-daerah kabupaten dan kota memfasilitasi jalannya kegiatan mengenai permainan tradisional. Namun demikian, apabila dari pihak pemerintah setempat tidak memiliki upaya untuk melestarikannya dan antusiasme dari masyarakat kurang dalam mengikuti kegiatan tersebut otomatis tingkat eksistensi permainan tradisional semakin menurun. Beliau mengungkapkan perlu adanya kreativitas dari generasi sekarang untuk bisa mengemas permainan tradisional khususnya engklek menjadi sesuatu yang dapat menarik minat anak-anak terhadap permainan tersebut.

Dampak dari kemajuan teknologi cenderung mengurangi kegiatan bermain permainan tradisional, namun di satu sisi penggunaan ilmu pengetahuan modern dapat menjadi terobosan baru untuk mengatasi permasalahan tersebut. Perkembangan teknologi dan informasi memberikan pengalaman hidup baru yang belum dijumpai sebelumnya. Piliang,Y.A (2005:221) menuturkan bahwa segala macam realitas masa lalu, sekarang telah digantikan oleh realitas baru. Permainan tradisional biasa diwariskan secara turun temurun dari satu generasi ke generasi 
selanjutnya. Permainan tradisional akan semakin terlupakan jika hanya mengandalkan cara-cara pengenalan tradisional. Pengenalan permainan tradisional perlu dilakukan melalui pendekatan modern menggunakan keterlibatan teknologi. Perkembangan teknologi informasi yang cukup populer saat ini adalah multimedia, yang mampu mampu mengubah dari satu media ke media lain secara leluasa, yakni dari media teks ke media gambar dan suara, maupun media interaktif yang melibatkan berbagai indera (Negroponte, 1998:26). Game merupakan salah satu produk multimedia interaktif. Game sangat berpotensi untuk menumbuhkan kembali motivasi keingintahuan anak terhadap pengetahuan yang mengalami penurunan (Buckingham \& Scalon, 2002).

\section{METODE PENELITIAN}

\section{1 metode Penelitian}

Metode penelitian yang digunakan adalah metode kualitatif yang dapat mendiskripsikan secara mendetail mengenai hubungan antara variabel aplikasi dan permainan tradisional engklek. Data-data yang dibutuhkan untuk merancang aplikasi permainan anak tradisional engklek diperoleh dari wawancara, angket, dokumentasi dan studi pustaka serta artikel internet berkaitan dengan permasalahan yang dihadapi yaitu permainan tradisional semakin ditinggalkan di zaman modern. Perancangan aplikasi digital permainan tradisional engklek dilakukan sebagai solusi menjaga pelestarian kebudayaan Indonesia. Untuk mendapatkan data-data yang diperlukan, metode pengumpulan data dilakukan melalui :

a. Wawancara, yaitu dengan dengan mendatangi Dinas Pariwisata dan Kebudayaan Provinsi Jawa Tengah mengenai pengaruh permainan tradisional dan khususnya engklek terhadap perkembangan anak dan kebudayaan bangsa. Juga mengunjungi Dinas Kebudayaan dan Pariwisata Kota Semarang menemui narasumber di bidangnya untuk memperkuat data.

b. Dokumentasi, yaitu berupa hasil observasi terhadap perbandingan anak yang sedang bermain smartphone berisi permainan modern dengan anak-anak yang sedang bermain permainan tradisional engklek baik di perkotaan maupun di daerah pedesaan.

c. Studi Pustaka, yaitu melalui buku, jurnal, dan artikel di internet tentang permainan tradisional, game mobile, teori perkembangan anak usia dini, dan lain sebagainya.

\subsection{Permainan Tradisional}

Permainan tradisional hampir sama dengan permainan lain, namun yang membedakan adalah peraturan dari permainan tersebut sudah ada sejak zaman dahulu yang sudah diwariskan secara turun temurun 
dari nenek moyang dengan tujuan memperoleh

kegembiraan

(Danandjaja, 1987). Permainan tradisional memiliki peraturan pemain minimal dua orang atau lebih. permainan-permainan tersebut mengandung segi edukatif, pendidikan jasmani ( melatih fisik), kecermatan mata, daya pikir, apresiasi nilai seni, kesegaran rohani, dan lain sebagainya (Kurniati, 2006). Adapun beberapa manfaat permainan tradisional secara umum adalah :

a. Permainan tradisional yang diketahui anak-anak dapat membuat permainan tersebut dapat terus dilestarikan serta menjaga nilai-nilai leluhur.

b. Memberikan sarana bermain pada anak yang murah dan mudah juga dapat menanamkan rasa peduli dan cinta pada potensi lokal.

c. Meningkatkan rasa kekeluargaan dan kebersamaan pada anak sejak dini.

Ibu Eni selaku ketua seksi nilai budaya di Dinas Kebudayaan dan Pariwisata Provinsi Jawa Tengah menjelaskan sejumlah karakter yang dimiliki permainan traidisional dapat membentuk karakter positif pada anak. Pertama, permainan tradisional cenderung menggunakan atau memanfaatkan alat di lingkungan sekitar tanpa harus membeli sehingga perlu daya imajinasi dan kreativitas yang tinggi, seperti memanfaatkan tumbuhan, tanah, genting, batu, atau pasir. Kedua, permainan anak tradisional melibatkan permain yang relatif banyak. Sebab, selain mendahulukan faktor kesenangan bersama, permainan ini juga mempunyai maksud lebih pada pendalaman kemampuan interaksi antar pemain (potensi interpersonal). Ketiga, permainan tradisional memiliki nilainilai luhur dan pesan-pesan moral tertentu seperti nilai-nilai kebersamaan, kejujuran, tanggung jawab, sikap lapang dada (apabila kalah), dorongan berprestasi, dan taat pada aturan.

Permainan tradisional saat ini sangat jarang dimainkan sehingga dapat musnah seiring berkembangnya zaman (Sukirman, 2008). Penting bagi berbagai pihak untuk turut serta melestarikan permainan tradisional melalui modifikasi pembelajaran sesuai dengan kondisi zaman yang serba modern ini.

\subsection{Permainan Engklek}

Engklek merupakan permainan tradisional yang memiliki bermacammacam sebutan diberbagai daerah, seperti Gala Asin (Kalimantan), Intingan (Sampit), Tengge-tengge (Gorontalo), Cak Lingking (Bangka), Dengkleng, Teprok (Bali), Gili-gili (Merauke), Deprok (Betawi), Gedrik (Banyuwangi), Bak-baan, engkle (Lamongan), Bendang (Lumajang), Engkleng (Pacitan), Sonda (Mojokerto), Tepok Gunung (Jawa Barat), ingkling, teklek, sunda manda (Sunda), lempeng, ciplak gunung, dampu, jlong jling, gejring, gedrik, dan lain-lain namun pada umumnya peraturan permainannya sama (Anang, 2013). Permainan engklek 
sangat baik untuk pertumbuhan anak. Anak menjadi sehat karena dalam bermain harus selalu aktif bergerak. Permainan engklek Juga dapat mengasah kejelian saat melempar batu dan belajar menjaga keseimbangan saat melompat. Sosialisasi dengan kawan saat bermain juga dapat menumbuhkan rasa kebersamaan dan keceriaan.

Pada umumnya prosedur permainan engklek adalah pemain melompati petak-petak sambil mengangkat satu kakinya hingga akhir permainan, namun terdapat pula petak yang harus diinjak dengan kedua kaki. Permainan ini membutuhkan gaco / gacu / gacuk ( biasanya menggunakan pecahan genting / keramik / batu pipih ) untuk dilempar ke dalam petak. Terdapat berbagai variasi peraturan permainan serta prosedur dalam permainan tradisional engklek yang disesuaikan dengan bentuk-bentuk petak engklek.Bentuk petak engklek antara lain :

\section{a. Bentuk Palang Merah}

Merupakan bentuk petak engklek yang terdiri dari 7 buah petak dan seperti namanya, petak-petak tersebut tersusun hingga menyerupai bentuk lambang palang merah atau dapat juga disebut sebagai bentuk pesawat. Aturan permainan pada bentuk petak ini yaitu setelah melempar gaco, pemain harus melompat pada petak yang tidak terdapat gaco milik sendiri. Urutan petak yang dilompati adalah: petak 1, petak 2, dan petak 3 dilompati dengan 1 kaki, kemudian di petak 47, petak 5-7, dan petak 6-7 dilompati dengan dua kaki ( masing-masing kaki pada satu petak), sedangkan pada petak 7 pemain boleh menginjak dengan kedua kaki di petak tersebut. Lalu melompat kembali hingga ke posisi awal.

\section{b. Bentuk Gunungan}

Pada bentuk gunungan / gunung terdapat 9 petak yang salah satunya berbentuk setengah lingkaran dimana memperbolehkan pemain untuk beristirahat sejenak di petak tersebut ketika sedang mendapat giliran main. Selain itu juga terdapat petak tunggal yang harus dilompati dengan satu kaki, dan petak berhimpitan/sejajar yang harus diinjak bersamaan ( masing-masing kaki pada satu petak ). Aturan permainannya adalah pemain melompati petak secara berurutan sesuai nomor pada petak, mulai dari petak 1 sampai dengan petak 8 , kemudian berbalik badan dan melompat lagi kembali ke posisi awal.

\section{c. Bentuk Baling-Baling}

Sesuai dengan namanya, bentuk petak ini menyerupai baling-baling atau biasa disebut juga dengan kincir / kitiran. Prosedur melompat pada petak berbentuk baling-baling ini yaitu permainan dimulai dari petak 1 , pemain melompati petak 1 , petak 2, dan petak 3 dengan satu kaki. Kemudian melompat pada petak 4 dan petak 8 bersamaan dengan dua kaki ( masing-masing petak satu kaki ), dilanjutkan petak 5 dan petak 8, kemudian petak 6 dan petak 8, lalu petak 7 dan petak 8 . Selanjutnya melompat dengan kedua kaki di petak 8 dan melompat kembali 
hingga ke petak 1 menggunakan satu kaki hingga sampai pada posisi awal sambil membawa gaco miliknya sendiri.

\section{d. Bentuk Bulet Payung}

Ciri khas dari bentuk petak ini adalah terdapat lingkaran besar pada ujungnya sehingga menyerupai payung yang sedang terbuka lebar. Prosedur permainannya yaitu dari petak awal berlanjut melompati petak berurutan mengelilingi lingkaran dengan arah berlawanan dengan jarum jam, kemudian melompat kembali ke petak awal. Pertama, pemain melempar gaco ke petak 1. Kemudian mulai melompat ke petak 2 lalu ke petak 3 dengan satu kaki, lalu serentak menginjakkan kaki kanan dan kaki kiri, yaitu kaki kiri di petak 11 dan kaki kanan di petak 4. Kemudian menginjakkan kaki kanan di petak 11 disusul dengan memindahkan kaki kiri ke petak 4 bersamaan dengan kaki kanan di petak 5. Berlanjut terus sesuai nomor, hingga kembali ke petak 1 atau posisi awal.

\section{e. Bentuk Menara}

Petak bentuk ini hampir sama dengan bentuk gunungan, hanya saja pada bagian ujung petak berbentuk segitiga sehingga menyerupai menara. Prosedur permainan dimulai dari pemain melempar gaco di petak 1, kemudian mulai melompat dengan sat kaki ke petak 2, lalu petak 3. Dilanjutkan dengan serentak menginjakkan kaki kanan dan kiri, kaki kanan di petak 4 dan kaki kiri di petak 5. Lalu melompat dengan satu kaki lagi di petak 6, terus petak 7. Kembali lagi melompat dengan cara yang sama sampai ke posisi awal.

\section{f. Bentuk Sorok}

Engklek berbentuk sorok ini agak berbeda dengan cara bermain bentuk petak yang lain, perbedaannya adalah jika bentuk petak yang lain pemain harus melompat, namun pada bentuk sorok pemain harus menyaruk batu yang telah dilempar. Pemain harus melempar gaco ke petak 1. Lalu pemain mendorong/tendang sambil melompat menggunakan ujung kaki, hingga sampai di petak gunung, kedua kaki boleh menginjak gunung. Kemudian gaco diambil dan dilempar lagi di petak selanjutnya hingga kembali lagi ke posisi awal.

\subsection{Perkembangan anak}

Perkembangan anak cenderung dapat meningkat karena melakukan berbagai macam hal atas dasar rasa keingintahuan, penasaran, dan inisiatif sendiri yang didukung oleh didikan orang tua untuk membantu memilihkan hal yang baik dan hal yang buruk untuk anak-anak mereka. Perkembangan anak tidak hanya semakin bertumbuhnya fisik saja, namun juga pada sedemikian rupa proses perubahan jasmani serta rohani anak yang berakhir ke fase akhir yaitu kematangan kepribadian anak melalui belajar dan bermain (Desmita, 2005).

Menurut buku 'Games Therapy untuk Kecerdasan Bayi dan Balita' yang ditulis oleh Psikolog Effiana Yuriastien, dkk ada 9 manfaat bermain bagi anak: 
a. Memahami diri sendiri dan mengembangkan harga diri.

b. Menemukan apa yang dapat mereka lakukan dan mengembangkan kepercayaan diri.

c. Melatih mental anak.

d. Meningkatkan daya kreativitas dan membebaskan anak dari stress.

e. Mengembangkan pola sosialisasi dan emosi anak.

f. Melatih motorik dan mengasah daya analisa anak.

g. Penyaluran bagi kebutuhan dan keinginan anak.

h. Standar moral.

i. Mengembangkan otak kanan atau kreativitas anak.

Menurut Sujono Riyadi (2009), pola bermain pada anak dipengaruhi lima faktor, yaitu :

a. Tahap perkembangan, perkembangan setiap anak mempunyai potensi/ keterbatasan tersendiri dalam bermain.

b. Status kesehatan, ketika anak sakit kemampuan psikomotor/ kognitif terganggu yang mengakibatkan anak tersebut menjadi sangat ambisius pada permainannya dan sebaliknya ada pula saat dimana anak sama sekali tidak tertarik bermain.

c. Jenis kelamin, biasanya anak laki-laki malu apabila diminta bermain dengan anak perempuan sehingga memungkinkan anak-anak untuk membentuk komunitas sendiri sesuai dengan jenis kelamin, dimana anak wanita bermain sesama wanita atau sebaliknya. Hal ini menyebabkan tipe dan alat permainan pun berbeda.

d. Lingkungan, letak dan lokasi tempat tinggal anak sangat mempengaruhi pola permainan yang dimainkan, seperti pola bermain anakanak di kota-kota besar berbeda dengan pola bermain anak-anak di desa.

e. Alat permainan, menyesuaikan dengan tahap perkembangannya sehingga anak merasa cocok untuk menggunakannya.

Sifat hiburan yang didapat dalam permainan dapat menjadi motivasi anak untuk belajar dan memahami segala sesuatu dengan lebih cepat. Bagi anak-anak, game sebagai media pembelajaran sangat bagus diterapkan untuk melatih kecepatan pemahaman materi sehingga dapat menjadi perbandingan dengan cara mengajar pada umumnya di sekolah (Vivrou, 2005). Penelitian lain yang juga menyimpulkan bahwa media pembelajaran yang tepat mempengaruhi peningkatan nilai pelajaran anak (Sudjana \& Rivai, 2005). Walaupun demikian, sudah menjadi kecenderungan anak-anak untuk senang bermain, karena dengan bermain bebas dapat menimbulkan perasaan senang (Tedjasaputra, 2001).

\subsection{Game}

Game merupakan permainan digital yang dirancang melalui suatu 
aplikasi dengan memanfaatkan kemampuan maksimal dari komputer. Game berkembang dalam masyarakat sebagai bentuk media bersosialisasi dan hiburan, dengan adanya game maka tercipta interaksi sosial yang tidak hanya bersifat lokal, namun berkembang hingga antar Negara. Seiring berkembangnya teknologi, game tidak saja sebagai sarana hiburan, juga dapat mengajarkan berbagai ketrampilan dari segi pendidikan (Buckingham \& Scalon, 2002). Keuntungan game sebagai sarana pengetahuan bagi anak (Smaldino, 2000) dijabarkan sebagai berikut :

a. Game mempunyai unsur menyenangkan bertentangan dengan belajar yang dianggap membosankan. Sehingga apabila kedua hal tersebut dilakukan bersamaan, anakanak mendapatkan kesenangan dalam bermain sekaligus pengetahuan yang bermanfaat.

b. Anak-anak cenderung mempunyai rasa ketertarikan terhadap segala sesuatu yang baru. Penyediaan game untuk belajar dapat mengurangi rasa bosan dari keseharian belajar di dalam kelas.

c. Suasana senang dan santai timbul saat anak bermain merupakan poin untuk membantu anak yang kesulitan menerima pelajaran yang statis.

d. Pemberian tugas berulangulang tidak lagi membuat anak malas karena tertutup oleh interaksi game yang menarik.

\section{HASIL DAN ANALISIS}

\section{PERANCANGAN GAME}

Pada zaman yang mengedepankan teknologi seperti sekarang ini, banyak faktor yang mendorong anakanak cenderung menghabiskan waktu bersama gadget, sehingga mereka menjadi kurang mengetahui dan tidak mengenal permainan tradisional terlebih permainan engklek. Padahal permainan tersebut telah terbukti memiliki banyak manfaat dari segala aspek bagi perkembangan kepribadian anak. Dalam rangka mengantisipasi kepunahan permainan tradisional engklek maka akan dibuat sebuah game permainan anak tradisional engklek yang merupakan serious game yaitu game memiliki sifat mempengaruhi/ motivatif yang dapat menumbuhkan kesadaran dan mengubah pandangan terhadap suatu hal bagi pemain game tersebut.

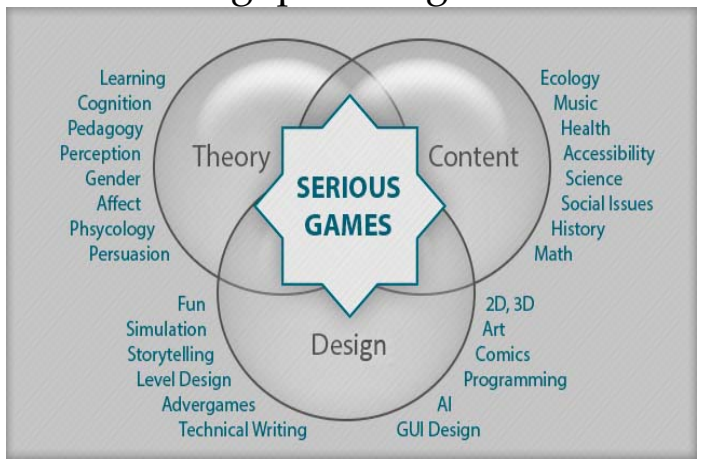

Pembuatan game permainan anak tradisional engklek ini bertujuan untuk mengenalkan permainan tradisional engklek guna melestarikan kebudayaan permainan tradisional engklek kepada anak- 
anak Indonesia khususnya bagi yang tinggal di daerah perkotaan saat ini. Sehingga di dalam game tersebut pemain dapat mengetahui segala hal tentang engklek, mulai dari bentuk petak, prosedur permainan, juga pengetahuan mengenai engklek dalam bentuk cerita bergambar dan animasi yang disukai anak-anak.

Pemilihan nama yang digunakan untuk game ini adalah "PERON Engklek". PERON merupakan singkatan dari PERmainan tradisiONal, dan Engklek yang merupakan nama dari permainan itu sendiri. Penyingkatan kata Permainan Tradisional menjadi PERON bertujuan supaya mudah diucapkan, mudah diingat, dan mudah dimengerti bahwa ini merupakan sebuah game mengenai permainan tradisional. Dan mengingat sangat banyak sebutan nama untuk permainan ini di berbagai daerah Indonesia, maka dipilih ENGKLEK karena berdasarkan survey yang dilakukan, sebutan tesebut lebih familiar terdengar oleh masyarakat hingga berbagai daerah daripada nama sebutan lain.

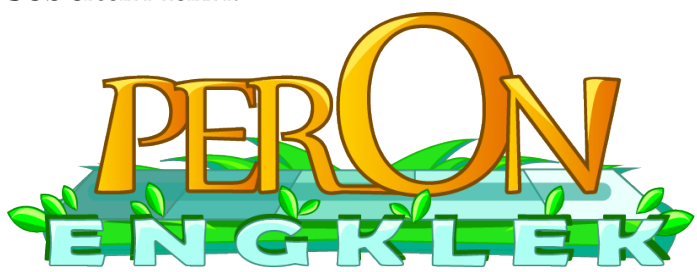

Untuk dapat lebih memahami gameplay PERON Permainan Tradisional Engklek ini, diamati melalui sudut pandang elemen formal dan dramatis antara lain sebagai berikut:

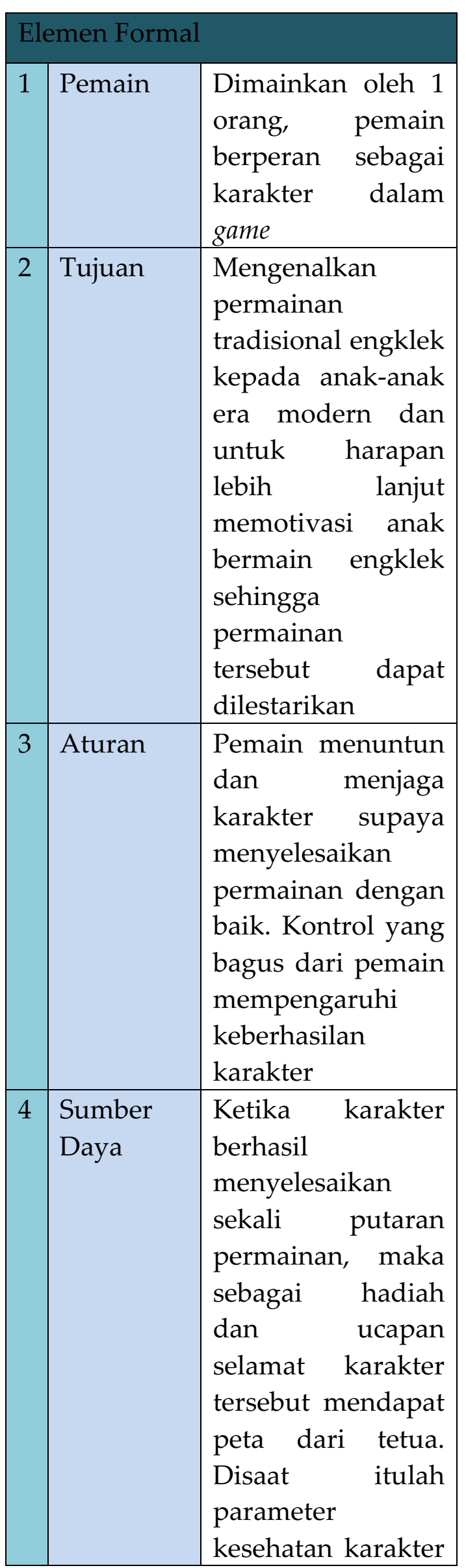




\begin{tabular}{|c|c|c|}
\hline & & bertambah \\
\hline 5 & Konflik & $\begin{array}{l}\text { Pemain harus } \\
\text { menghentikan } \\
\text { roda putar dengan } \\
\text { tepat supaya } \\
\text { karakter dapat } \\
\text { dengan tepat pula } \\
\text { melempar gaco } \\
\text { dan karakter dapat } \\
\text { mulai melompat. } \\
\text { Dilanjutkan } \\
\text { dengan menjaga } \\
\text { posisi ikon telapak } \\
\text { kaki tetap berada } \\
\text { di tengah kotak } \\
\text { supaya karakter } \\
\text { tidak terjatuh saat } \\
\text { melompat }\end{array}$ \\
\hline 6 & Batasan & \begin{tabular}{lr} 
Jika & \multicolumn{2}{r}{ parameter } \\
kesehatan habis, \\
maka misi gagal \\
dan permainan \\
selesai
\end{tabular} \\
\hline 7 & Hasil & $\begin{array}{l}\text { Karakter } \\
\text { menemukan petak } \\
\text { engklek yang } \\
\text { tersembunyi dan } \\
\text { telah dapat } \\
\text { memainkannya } \\
\text { dengan baik }\end{array}$ \\
\hline \multicolumn{3}{|c|}{ Elemen Dramatis } \\
\hline 1 & Tantangan & $\begin{array}{l}\text { Dalam bermain } \\
\text { engklek } \\
\text { diperlukan } \\
\text { kecermatan, } \\
\text { ketangkasan dan } \\
\text { keseimbangan } \\
\text { yang bagus. Poin- } \\
\text { poin tersebut juga } \\
\text { diaplikasikan ke } \\
\text { dalam game ini, } \\
\text { sehingga pemain }\end{array}$ \\
\hline
\end{tabular}

\begin{tabular}{|c|c|c|}
\hline & & $\begin{array}{l}\text { harus cermat } \\
\text { dalam } \\
\text { menghentikan } \\
\text { roda putar dan } \\
\text { tetap menjaga } \\
\text { keseimbangn } \\
\text { karakter saat } \\
\text { melompat }\end{array}$ \\
\hline 2 & Play & $\begin{array}{l}\text { Karakter } \\
\text { menghidupkan } \\
\text { kembali } \\
\text { permainan } \\
\text { legendaris dengan } \\
\text { cara mencari petak } \\
\text { engklek yang } \\
\text { tersembunyi di } \\
\text { suatu pulau }\end{array}$ \\
\hline 3 & Motif & $\begin{array}{l}\text { Mengenal dan } \\
\text { mengetahui } \\
\text { prosedur } \\
\text { permainan } \\
\text { engklek serta } \\
\text { bentuk-bentuk } \\
\text { petak engklek } \\
\text { beserta cara } \\
\text { melompatnya }\end{array}$ \\
\hline 4 & Karakter & $\begin{array}{l}\text { Tersedia } 2 \text { karakter } \\
\text { utama yang dapat } \\
\text { dipilih pemain, } \\
\text { anak laki-laki dan } \\
\text { anak perempuan } \\
\text { yang pada } \\
\text { deskripsi karakter } \\
\text { dijelaskan } \\
\text { berumur } 10 \text { tahun. } \\
\text { Walaupun mereka } \\
\text { memiliki sifat } \\
\text { menonjol yang } \\
\text { bertolak belakang, } \\
\text { namun rasa } \\
\text { keingintahuan } \\
\text { terhadap sesuatu }\end{array}$ \\
\hline
\end{tabular}




\begin{tabular}{|c|c|c|}
\hline & & $\begin{array}{l}\text { hal sangat tinggi. } \\
\text { Selain itu terdapat } \\
\text { karakter pedukung } \\
\text { berwujud orang } \\
\text { lanjut usia dimana } \\
\text { menjaga bentuk } \\
\text { petak engklek } \\
\text { yang tersembunyi } \\
\text { tersebut }\end{array}$ \\
\hline 5 & Cerita & 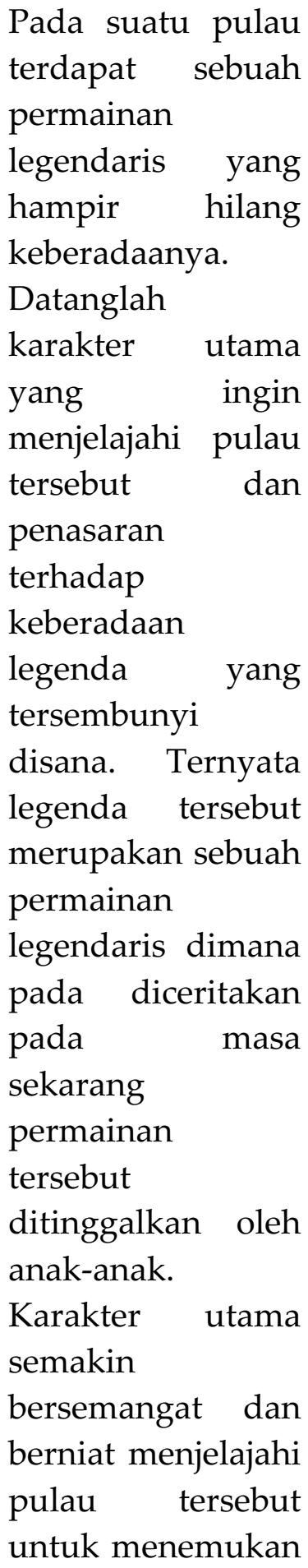 \\
\hline
\end{tabular}

\begin{tabular}{|l|l|}
\hline & dan memainkan \\
permainan \\
engklek \\
legendaris. Maka \\
petualangan \\
pencarian kembali \\
permainan \\
tersebut dimulai. \\
\hline
\end{tabular}

\subsection{Desain Karakter}

Terdapat 2 orang anak yang berperan sebagai karakter utama dalam game PERON Engklek, yaitu seorang anak laki-laki bernama Dop, dan seorang anak perempuan bernama Pod. Dop memiliki tubuh kecil sesuai dengan usia anak pada umumnya yang memiliki umur sekitar 5-8 tahun, rambut lemas acak-acakan sebagai tanda siap berpetualang kemana pun, mata tajam berbinar seakan menyatakan siap memulai tantangan baru, dan kulit warna sawo matang khas Indonesia. Pada keseluruhan penampilan Dop terlihat gaya tradisional Indonesia yang dipadukan dengan desain pakaian modern. Ini berfungsi sebagai penambah daya tarik anak-anak melalui konsep penampilan yang unik. Ciri khas karakter Dop adalah warna hijau tua, melambangkan mudah berbaur dengan alam sekitar. Selain itu terdapat aksesoris khusus yang mencitrakan sosok anak Indonesia, yaitu ikat kepala dengan sehelai daun segar dan ikat pinggang yang terbuat dari kain. Pod memiliki tubuh kecil sesuai dengan usia anak perempuan pada umumnya yang memiliki umur sekitar 5-8 tahun, rambut lurus panjang yang menonjolkan sisi feminim dengan 
mata cerah bersemangat dengan bulu mata panjang. Secara keseluruhan penampilan Pod menggambarkan seorang anak perempuan yang memiliki rasa keingin tahuan tinggi terhadap sesuatu hal baru. Warna kulit adalah warna sawo matang khas Indonesia. Pada keseluruhan penampilan Pod terlihat gaya tradisional Indonesia yang dipadukan dengan desain pakaian modern. Ini berfungsi sebagai penambah daya tarik anak-anak zaman sekarang melalui konsep penampilan yang unik. Ciri khas karakter Pod adalah warna merah muda, melambangkan sisi feminim dari seorang gadis. Selain itu terdapat aksesoris khusus yang mencitrakan sosok anak Indonesia, yaitu selendang dan sepatu selop.

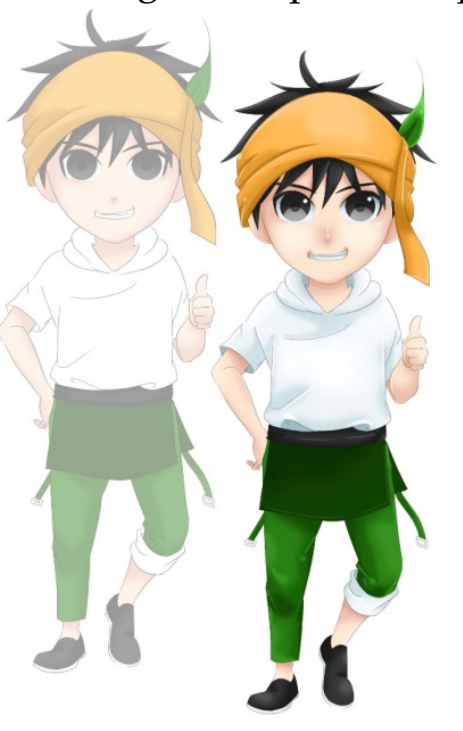

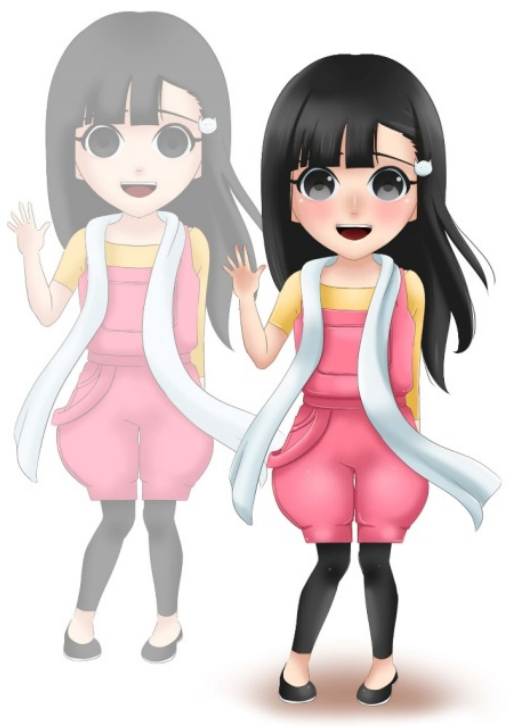

\subsection{Desain Environment}

Pada game PERON Engklek memakai environmet dominan pemandangan alam, karena lokasi game terdapat di sebuah pulau tersembunyi. Secara keseluruhan terdapat bangunan dan pemandangan suatu tempat di Indonesia, yang dipadukan dengan sedikit unsur fantasi. Sebelum memulai permainan, pemain harus memilih salah satu karakter yang telah disediakan. Environment yang terlihat pada scene tersebut adalah pemandangan 3 buah air terjun yang mengalir jernih. Karena ini adalah awal dari permainan akan dimulai, maka terdapat gapura yang terlihat di sisi kiri dan kanan. Gapura ini memiliki bentuk serta ukiran unik dan indah, yang terinspirasi dari Lempuyang Temple di Bali. Pemandangan tiga air terjun tersebut merupakan ilustrasi dari curug Cikaso di Sukabumi. 


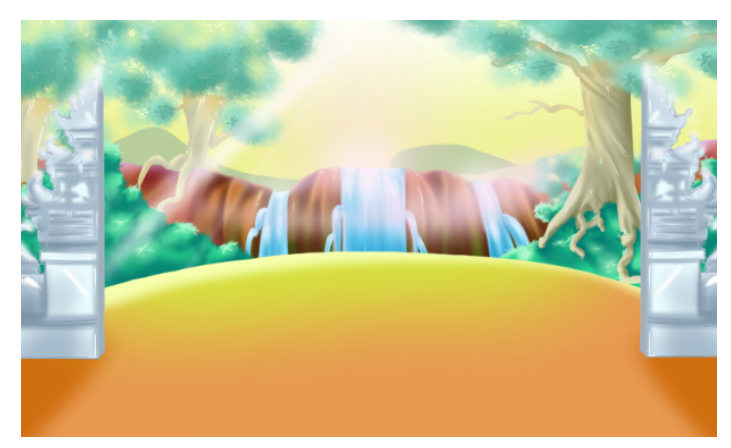

Environment terakhir di scene prolog adalah suatu tempat dari atas bukit. Di scene tersebut terlihat puncak bangunan dimana menyerupai sebuah bangunan yang sudah dikenal seluruh penduduk Indonesia, yaitu Candi Borobudur. Bagian atas bangunan tersebut mendapat referensi dari stupa Candi Borobudur, kemudian ditambah kesan fantasi dengan memberikan warna cerah.

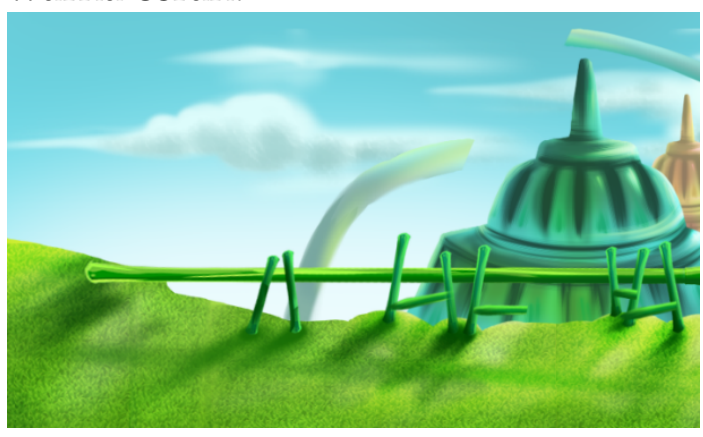

Setelah mengetahui penjelasan mengenai permainan legendaris di pulau tersebut, pemain siap bermain. Pada level pertama, lokasi permainan engklek adalah outdoor, yaitu pinggir hilir sungai di dalam hutan yang dipenuhi rerumputan hijau segar. Arena bermain engklek tersebut berada diatas kayu/ papan dengan tanaman merambat sebagai penyangga. Environment scene ini didesain simple atau tidak penuh karena akan ditambahkan banyak elemen yang melengkapi jalannya permainan. Pada bagian ujung kiri terlihat 2 batang bambu berwarna hijau yang banyak dijumpai di Indonesia.

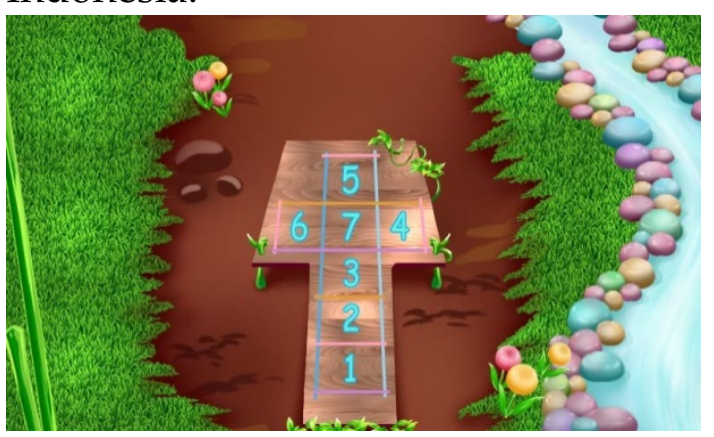

Jika pemain berhasil menyelesaikan 1 putaran penuh permainan level 1, maka mendapatkan bonus berupa informasi sepintas mengenai engklek dalam bentuk penggalan ilustrasi. Dimulai dari pada suatu sore terdapat anak berkulit putih sebagai anak Belanda sedang bermain engklek hingga terdapat juga anak bekulit coklat sebagai anak Indonesia juga bermain engklek dengan ramai di bawah pepohonan yang rindang. Terlihat rumah pohon yang merupakan ilustrasi dari rumah suku Korowai di Papua yang berada di ketinggian 15-50 meter di atas tanah, selain mendapat bonus, juga mendapat kesempatan memperoleh sebuah peta untuk menunjukkan lokasi permainan engklek selanjutnya.

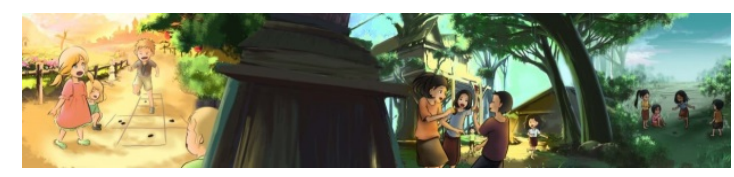

Environment pada scene ini menampilkan pemandangan terasering yang sejuk dan indah dengan langit biru cerah di pagi hari. Terasering ini akan bergeser sehingga gunung di belakangnya akan terlihat. 


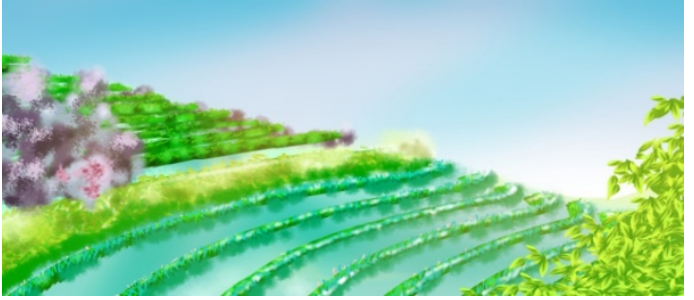

Pemilihan keseluruhan warna untuk environment disesuaikan dengan selera dan imajinasi anak-anak yaitu memadukan warna-warna cerah menjadi pemandangan yang indah.

\subsection{Desain User Interface}

User Interface pertama game PERON Engklek, terlihat kedua karakter berpose melompat, logo game, dan button mulai. Berikut beberapa desain user interface dari game PERON Engklek.

\begin{tabular}{|c|l|l|}
\hline Scene & Visual & $\begin{array}{l}\text { Keterang } \\
\text { an }\end{array}$ \\
\hline Mulai & $\begin{array}{l}\text { Scene utama } \\
\text { game } \\
\text { PERON } \\
\text { Engklek, } \\
\text { terlihat } \\
\text { kedua } \\
\text { karakter } \\
\text { berpose } \\
\text { melompat, } \\
\text { logo game, } \\
\text { dan button } \\
\text { mulai }\end{array}$ \\
\hline Menu & $\begin{array}{l}\text { Menu } \\
\text { game, scene } \\
\text { dimana } \\
\text { pemain } \\
\text { dapat } \\
\text { memilih } \\
\text { antara } \\
\text { langsung } \\
\text { bermain/m } \\
\text { elihat } \\
\text { petunjuk/t } \\
\text { entang }\end{array}$ \\
\hline & $\begin{array}{l}\text { Pemain } \\
\text { memilih } \\
\text { karakter } \\
\text { anak laki- }\end{array}$ \\
\hline
\end{tabular}

\begin{tabular}{|c|c|c|}
\hline & & $\begin{array}{l}\text { laki } \\
\text { bernama } \\
\text { Dop atau } \\
\text { anak } \\
\text { perempua } \\
\text { n bernama } \\
\text { Pod }\end{array}$ \\
\hline Main & $\frac{1}{3}=$ & $\begin{array}{l}\text { Mulai } \\
\text { bermain } \\
\text { engklek, } \\
\text { terdapat } \\
\text { karakter } \\
\text { Dop, petak } \\
\text { engklek, } \\
\text { pemutar } \\
\text { angka dan } \\
\text { kotak } \\
\text { keseimban } \\
\text { gan, serta } \\
\text { skor dan } \\
\text { bar } \\
\text { kesehatan }\end{array}$ \\
\hline Skor & $\mid \begin{array}{l}1 \\
+00\end{array}$ & $\begin{array}{l}\text { Tampilan } \\
\text { perolehan } \\
\text { skor akhir }\end{array}$ \\
\hline Petunjuk & 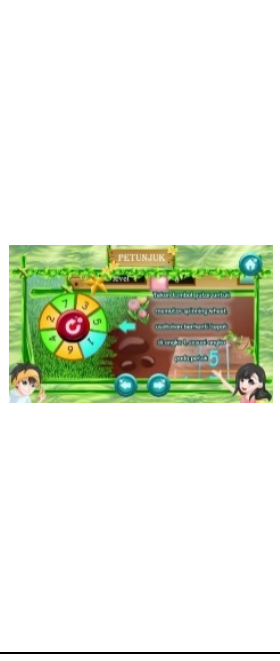 & $\begin{array}{l}\text { Petunjuk } \\
\text { menjelaska } \\
\mathrm{n} \\
\text { permainan } \\
\text { dimulai } \\
\text { dengan } \\
\text { melompati } \\
\text { petak } \\
\text { angka } 1 . \\
\text { Untuk } \\
\text { bermain } \\
\text { tekan } \\
\text { button } \\
\text { putar }\end{array}$ \\
\hline Tentang & 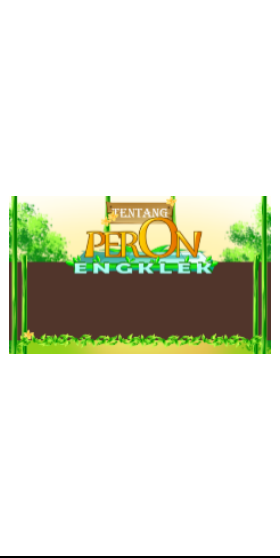 & $\begin{array}{l}\text { Terdapat } \\
\text { teks } \\
\text { bergerak } \\
\text { dari bawah } \\
\text { ke atas } \\
\text { yang berisi } \\
\text { informasi } \\
\text { tentang } \\
\text { developer } \\
\text { game } \\
\text { PERON } \\
\text { Engklek }\end{array}$ \\
\hline
\end{tabular}




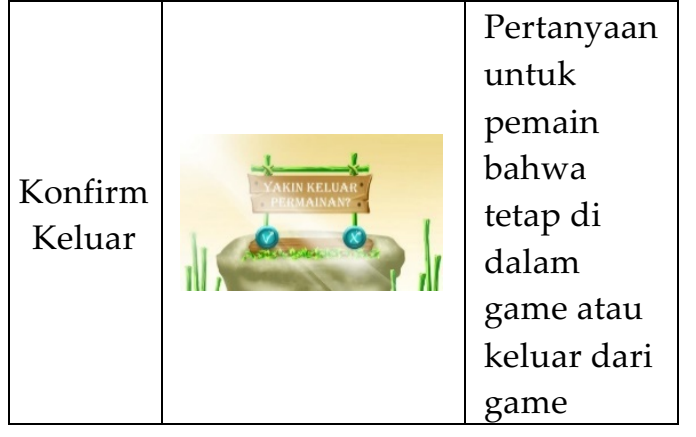

Visual user interface pada game PERON Engklek memakai warnawarna cerah karena disesuaikan dengan target audience yaitu anakanak.

\section{SIMPULAN}

Perancangan game PERON Engklek adalah sebagai salah satu wujud atas kepedulian akan pentingnya permainan tradisional khususnya engklek di zaman modern dan merupakan solusi alternatif mengatasi permasalahan bahwa permainan tersebut semakin ditinggalkan walaupun mempunyai banyak manfaat bagi anak-anak. Dalam game PERON Engklek, pemain akan ditunjukkan prosedur permainan dan gerakan karakter melompati petak engklek secara berulang-ulang. Pengenalan alur cerita dan misi di dalam game ini dapat menarik minat anak untuk bermain engklek. Hasil akhir dari proses produksi ini adalah sebuah game Android PERON Engklek yang dapat mengenalkan permainan tradisional engklek melalui teknologi digital kepada anak-anak generasi modern sehingga memotivasi mereka untuk bermain bersama temantemannya. Sehingga diharapkan dapat menjaga permainan tersebut mengalami kepunahan.

Melalui perancangan game PERON Engklek, diharapkan pelestarian permainan tradisional engklek melalui media digital sebagai sarana alternatif mendapatkan dukungan dalam segi positif. Namun menjaga permainan tradisional engklek agar tidak mengalami kepunahan di zaman modern ini tidak hanya dapat ditunjang melalui adanya media game saja, akan tetapi peran dari berbagai pihak, baik pihak masyarakat Indonesia khususnya para orangtua, tenaga pengajar di lingkup sekolah serta pihak pemerintah yaitu Dinas Kebudayaan dan Pariwisata untuk mempromosikan game ini akan mendapat pengaruh besar.

\section{REFERENSI}

Anang. (2013, Februari 23). Anangpedia. Retrieved from http://anangelnino.blogspo t.co.id/2013/02/dolananengklek.html

Buckingham, D., \& Scalon. (2002). The effects of violent video game habits on adolescent hostility, aggressive behaviours, and school performance. Journal of Adolescence.

Danandjaja, J. (1987). Floklore Indonesia. Jakarta : Gramedia. . Jakarta: Gramedia.

Desmita. (2005). Psikologi Perkembangan. Bandung: Remaja Rosda Karya. 
Kurniati, E. (2006). Konsep dasar Bermain di Taman Kanakkanak. Bandung: Universitas Pendidikan Indonesia.

Kusmara, A. Rikrik DKK, Ed Setiawan Sabana dan Hawe Setiawan, 2005. Legenda Kertas:Menelusuri Jalan Sebuah Peradaban. Bandung : Kiblat.

Negroponte, Nicholas, 1998. Being Digital : Menyiasati Hidup dalam Cengkraman Sistem Komputer. Bandung. Mizan

Smaldino, S. (2000). Instructional Technology and Media for Learning. Upper Saddle River: Pearson Merill Prentice Hall.

Sudjana, N., \& Rivai, A. (2005). Media Pengajaran. Bandung: Sinar Baru Algensindo.

Sujianto, Agus. 1996. Psikologi Perkembangan. Surabaya: PT Rineka Cipta.

Sukirman, D. (2008). Permainan Tradisional Jawa. Yogyakarta: Kepel Press Puri arsita A-6.

Tedjasaputra, M. S. (2001). Bermain, Mainan, dan Permainan. Jakarta: PT. Gramedia Mediasarana Indonesia.

Vivrou, M. (2005). Combining Software Games with Education: Evaluation of its Educational Effectiveness. Greece: University Of Piraeus. 